Egyptian J. of Nutrition Vol. XXXVI No. 1 (2021)

\title{
Effect of Sage, Sesame and Olive Oils Alone and in Combination with Sage on Weight Reduction and Fasting Blood Sugar in Obese Non-Alcoholic Fatty Liver Albino Rats.
}

\author{
Hadeer Ashraf Abd El-Aziz Abd EI-Megeid*, Seham A.M. \\ Tharwat $^{\star \star}$, Sonia S. El-Marasy ${ }^{\star \star}$ and Ahmed E. Basyony. ${ }^{\star \star \star}$ \\ * Graduate student, Nutrition and Food Science Dept. Faculty of \\ Home Economics, Helwan University, Egypt. \\ ${ }^{*}$ Department of Nutrition and Food Science, Faculty of Home \\ Economics, Helwan University, Egypt. \\ *** Department of Biochemistry, Food Technology Institute, Egypt.
}

\begin{abstract}
The aim of this study was to investigate the effects of sage, sesame and olive oils alone and in combination with sage on daily feed intake (FI), body weight gain\% (BWG\%), organs weight to body weight ratio, peritoneal fat pad ratio, serum blood glucose and leptin hormone in nonalcoholic fatty liver disease (NLFLD). A total of 72 adult male albino rats of Spragu-Dawley Strain weighing $200 \pm 10 \mathrm{~g}$ were used in this study. The rats were divided into two main groups. The first group (8 rats) was fed on basal diet (BD) and used as a control negative group (-ve). The second main group (64 rats) was fed on high fat diet (HFD) for (8) weeks to induce non-alcoholic fatty
\end{abstract}


Hadeer Ashraf Abd El-Aziz Abd El-Megeid, Seham A.M. Tharwat, Sonia S. El-Marasy and Ahmed E. Basyony.

liver disease (NLFLD). NLFLD rats were divided into (8 subgroups).

One of them (8 rats) was fed on (HFD), used as a positive control group (+ve). The other (7 subgroups) fed on modified (HFD), one of them by adding $5 \%$ sage. The other subgroups were fed on modified (HFD) by replace $20 \%$ sheep tallow (ST) to $20 \%$ sesame oil (SO), $20 \%$ olive oil (OO) and mixed $10 \%$ (SO) with $10 \%$ (OO) without or with sage for (8 weeks). At the end of experiment, rats were anesthetized by ether before sacrificing after fasting overnight, liver, kidney and peritoneal fat pad were then taken and weighted. Blood samples were collected, left to clot, the serum was separated, glucose and leptin level were determined. The obtained results revealed that, feeding obese (NLFLD) rats on modified high fat diet (MHFD) containing $5 \%$ sage or by replacing $20 \%$ (ST) to $20 \%$ (OO), $20 \%$ (SO) or mixed $10 \%$ (SO) with $10 \%$ (OO) plus or without $5 \%$ sage significantly decreased body weight gain\%, relative weight of liver, kidney and peritoneal fat pad\%, serum fasting blood glucose and leptin hormone. Our results revealed that, mixed 10\% (SO) with $10 \%(0 O)$ plus $5 \%$ sage may represent a potentially therapeutic provide the greatest activity decrease in BWG\%, organs weight / body weight $\%$, peritoneal fat pad\%, fasting blood glucose and leptin hormone level of obese nonalcoholic fatty liver disease (NLFLD) in rats. 
Egyptian J. of Nutrition Vol. XXXVI No. 1 (2021)

\section{Introduction}

Non-alcoholic fatty liver disease affects $10-35 \%$ of adult population worldwide (Bellentani and Marino, 2009).When we consider the management of nonalcoholic fatty liver disease (NAFLD), two aspects should be considered. One is that can be a part of metabolic syndrome (Lonardo et al., 2015). About $80 \%$ of patients with metabolic syndrome have NAFLD (Antunes and Bhimji, 2017). Although the prevalence of NAFLD is $20-40 \%$ in the general population, about $70 \%$ of type 2 diabetes mellitus (Leite et al., 2009) and $85 \%$ of patients with morbid obesity (BMI $\geq 40$ ) have NAFLD (Fabbrini et al., 2009). In the general population, $80 \%$ of patients with NAFLD are overweight and $20 \%$ of NAFLD patients have normal weight as per ultrasonography (Bellentani and Tiribelli, 2001).

High fat diets (HFD) are well known to increase body weight, body fat and induce insulin resistance in rodent models (Samuel et al., 2004). On the other hand, YKi-Jarvinen, (2005)reported that, dietary fat content modifies liver fat in overweight non diabetic subjects. Decreasing total fat consumption and shifting to monounsaturated fatty acids MUFAs found in olive oil (20-40\%) of total energy or $\mathrm{n}-3$ PUFAs found in fish oil $(2 \mathrm{~g} / \mathrm{d})$ could lead to a decrease in postprandial lipidemia and steatosis (Capanni et al., 2006). Sesame oil, which is extracted from sesame seeds, contains both monounsaturated fatty acids and polyunsaturated fatty acids. Sesame oil contains vitamin $\mathrm{E}$ and other antioxidant compounds 
Hadeer Ashraf Abd El-Aziz Abd El-Megeid, Seham A.M. Tharwat, Sonia S. El-Marasy and Ahmed E. Basyony.

known as lignans. Lignans acts as compounds important for antioxidant activity since they help the absorption of vitamin $E$ and other phytochemical (Sankar et al., 2006).

Herbal treatment of many diseases including hepatopathy is increasing in many countries. Some plants have been shown to have protective antioxidant effects and are therefore hepatoprotective. Such plants include sage "Salvia officials L". (Carla et al., 2009).Salvia officials $L$ (Sage) has been reported to have a wide range of biological activities, such as antioxidants, antibacterial, hypoglycemic and anti-inflammatory properties. Recent studies have found that the sage has positively physiological effects on heart, liver, kidney and testes (Chien et al., 2011). Therefore, this study aimed to investigate the effects of sage, sesame and olive oils alone and combination the oils with sage on daily feed intake $(\mathrm{FI})$, body weight gain\% (BWG\%), organs weight to body weight ratio, peritoneal fat pad ratio, serum glucose and leptin hormone in obese Non-Alcoholic Fatty Liver Albino Rats.

\section{Materials and Methods}

Material: Casein, vitamins, minerals, cellulose, and choline chloride were purchased from El- Gomhoria Company, Cairo, Egypt. Soy, sesame and olive oils were obtained from Agricultural Research Center, Giza, Egypt. Sage was obtained from the National market of Agricultural herbs and medicinal plants, Cairo, Egypt. Kits for 
Egyptian J. of Nutrition Vol. XXXVI No. 1 (2021)

biochemical analysis were obtained from Alkan for pharmaceutical and chemical Dokki, Egypt.

Rats: Seventy - two adult male albino rats (Spragu Dawley Strain) were purchased from Helwan farm of experimental animals, Ministry of Health and population, Helwan, Cairo, Egypt.

\section{Methods:}

\section{Experimental Design:}

After acclimation on a basal diet (BD) for one week, rats were classified into two main groups. The first main group $(n=8)$ fed on BD as a control negative group (-ve). The second main group (64) rats were fed on high fat diet (HFD) to induce nonalcoholic fatty liver disease according to (Zarghani et al., 2016). After 8 weeks' body weight gain \%, serum lipid; cholesterol and triglycerides were determined for first and second main groups to insure the induction of obesity and fatty liver, then the second main group fed on (HFD) for 8 weeks and then were divided into eight subgroups:

-The first group fed on (HFD) all over the experimental period, as a control positive group (+ve).

-The second group fed on HFD containing $5 \%$ sage.

-The third and fourth groups fed on modified high fat diet (MHFD) by replace $20 \%$ (ST) to $20 \%$ olive oil (OO) or $20 \%$ sesame oil (SO), respectively.

-The fifth and sixth groups fed on modified high fat diet (MHFD) by replace $20 \%$ (ST) to (10\% OO and $10 \% \mathrm{SO})$ or $(10 \% \mathrm{OO}$ and $10 \%$ SO) plus $5 \%$ sage, respectively. 
Hadeer Ashraf Abd El-Aziz Abd El-Megeid, Seham A.M. Tharwat, Sonia S. El-Marasy and Ahmed E. Basyony.

-The seventh and eighth groups were fed on modified high fat diet (MHFD) by replacing $20 \%$ (ST) to $20 \%$ (SO) plus $5 \%$ sage and $20 \%$ SO plus $5 \%$ sage, respectively.

\section{Biological Evaluation:}

Daily feed intake (FI) and body weight gain\% (BWG\%) were checked once a week. At the end of the experimental period (8 weeks) daily feed intake (FI), body weight gain (BWG \%) and organs weight / body weight were specified according to the method of (Chapman et al., 1959). Animals were fasted overweight, and then anesthetized by very light ether before sacrificing. Blood samples were collected from hepatic portal vein of each rat. Serum were carefully separated by centrifugation of blood sample. Then kept frozen at $-20^{\circ} \mathrm{C}$ Until the analysis is done. Liver, kidneys and peritoneal fat pad were taken from rats by careful dissection, washed in saline solution (0.9\%) and lastly dried using filter paper and independently weighed.

\section{Biochemical analysis:}

Determination of serum leptin was done according to (Guillaume and Bjorntorp 1996)and serum glucose according to Trinder (1969).

\section{Statistical Analysis:}

Results of biochemical analysis and biological evaluation of each group were statistical analyzed, mean, standard error and oneway ANOVA test using SAS package with level of significant $p<0.05$ (SAS, 2004). 
Egyptian J. of Nutrition Vol. XXXVI No. 1 (2021)

Results and Discussion

Effects of sage, sesame and olive oils alone or in combination on feed intake and body weight gain $\%$ in obese nonalcoholic fatty liver rats.

Table (1) illustrate the effects of high fat diet (HFD) alone or with modification by adding $5 \%$ sage or by replacing (20\%) (ST) to $20 \%$ olive oil (OO), $20 \%$ sesame oil (SO), $20 \%$ mixed (OO) with (SO) $(1: 1$ W/W) without or with $5 \%$ sage on feed intake ( $\mathrm{FI})$ and body weight gain \% (BWG\%). Results revealed that the (-ve) group fed on basal diet $(B D)$ recorded a significant increase $(p<0.05)$ in $\mathrm{Fl}$, as compared to the control (+ve) fed on (HFD). While (+ve) control group which fed on (HFD) with modification by adding $5 \%$ sage, or by replacing $20 \%$ sheep tallow (ST) to $20 \%$ (SO), $20 \%$ (OO) or $20 \%$ from mixed (SO) plus (OO) $(1: 1 \mathrm{~W} / \mathrm{W})$ with or without $5 \%$ sage, our results revealed that, there is no significant difference in FI between (+ve) control group and all groups which fed on (HFD) with different modifications. However, the caloric intake of albino rats fed on (BD) (ve) group was lower, as compared to the (HFD) groups. We also found that no significant difference in (FI) between (+ve) control group fed on (HFD), as compared to the other groups fed on modified (HFD).

Concerning body weight gain \% (BWG\%) Table (1) shows that (-ve) group fed on (BD) and (+ve) group fed on (HFD) recorded (19.260 \pm 0.708 vs $29.724 \pm 1.084$, respectively). Results revealed a significant increase $(P<0.05)$ in BWG \% of the $(+v e)$ group, as 
Hadeer Ashraf Abd El-Aziz Abd El-Megeid, Seham A.M. Tharwat, Sonia S. El-Marasy and Ahmed E. Basyony.

compared to the (-ve) group. However, the caloric intake of albino rats (-ve) group fed on (BD) was lower as compared to the (HFD) groups. Concerning groups which fed on modified (HFD) by adding $5 \%$ sage or by replacing $20 \%$ sheep tallow (ST) to $20 \%$ (OO), $20 \%$ (SO), $20 \%$ mixed from $10 \%$ (SO) plus $10 \%$ (OO) (1:1 W/W) with or without $5 \%$ sage. Results revealed a significant decrease $(P<0.05)$ of all treated groups fed on modified (HFD), as compared to the (+ve) group fed on (HFD). On the other hand, our results revealed that the best results as induced decrease in BWG\% recorded by (+ve) group (NAFLD) fed on modified (HFD) by replacing 20\% (ST) to $20 \%$ from mixed $10 \%(\mathrm{OO})$ with $10 \%$ (SO) plus $5 \%$ sage, followed by the (+ve) group fed on modified (HFD) by replacing [20\% (ST) to $20 \%(\mathrm{OO})$ ] plus $5 \%$ sage. Our results revealed that the combination between $10 \%(\mathrm{OO})$ with $10 \%(\mathrm{SO})$ plus $5 \%$ sage induced high potential effects on reducing BWG \% in (NAFLD) fed on (HFD). Our results revealed that sage species might potentially provide naval natural treatment for the cure of obesity.

In this concern (Hamidpour et al., 2014) suggested that salvia species, in addition to treating minor common illness, might potentially treatment for relief of many diseases such as depression, dementia, obesity, diabetes, lupus, heart disease and cancer, concerning the effect of (SO) our results are at the same line with (Hareeri et al., 2017)Who found that oral intake of sesame oil in the treated doses 4 and $8 \mathrm{ml} / \mathrm{kg} /$ body weight caused a significant $(\mathrm{p}$ $<0.05)$ decreased in BWG \%, as compared to (+ve) control group. 
Egyptian J. of Nutrition Vol. XXXVI No. 1 (2021)

Concerning the effects of MUFA in olive oil promoted benefits on weight reduction. in this concern (Kaippert et al., 2015) suggested that diet high in MUFA promoted benefits on weight loss and body composition in women with obesity. Olive oil causes weight reduction, decreases in the serum triglycerides (Wani et al., 2015).

Effects of sage, sesame and olive oils alone or in combination on peritoneal fat pad \% and some organs weight / body weight $\%$ in obese nonalcoholic fatty liver rats.

Table (2) illustrate the effects of (HFD) alone and modified (HFD) by adding $5 \%$ sage or by replacing $20 \%$ (ST) to $20 \%$ from (SO), (OO) or mixed $20 \%$ from $(1: 1 \mathrm{w} / \mathrm{w})(\mathrm{SO})$ plus $\mathrm{OO}$ without or with $5 \%$ sage on peritoneal fat pad \%(PFP \%) and some organs weight/body weight $\%$ (OW/BW \%).

Results revealed that PFP\%, liver and kidney weight for (-ve) group fed on (BD) recorded a significant decrease $(p<0.05)$, as compared to the (+ve) control fed on (HFD), on the other hand, our results revealed that all groups fed on modified (HFD) by adding $5 \%$ sage or replacing $20 \%$ (ST) to $20 \%$ from (SO), (OO) or $20 \%$ mixed between them $(1: 1 \mathrm{w} / \mathrm{w})$ without or with $5 \%$ sage induced a significant decrease $(\mathrm{P}<0.05)$ in PFP \% \& (OW / BW\%) when compared with + ve control group. The best results recorded by (+ve) obese (NAFLD) group which fed on modified (HFD) by replacing $20 \%$ (ST) to $20 \%$ from mixed $(\mathrm{SO})$ with $(\mathrm{OO})(1: 1 \mathrm{w} / \mathrm{w})$ plus $5 \%$ sage.

In this respect (Ben khedher et al., 2018)suggested that sage had efficacy in the prevention of lipid accumulation within 3T3L1 adipocytes in consistent with it reducing body weight gain (related 
Hadeer Ashraf Abd El-Aziz Abd El-Megeid, Seham A.M. Tharwat, Sonia S. El-Marasy and Ahmed E. Basyony.

adipose tissue hypertrophy) in (HFD) mice treated with low dose of sage. On the other side, our results are at the same line with (Han et al., 1999). Han et al., (2000)suggested that olive oil causes weight reduction, decreases the serum TG and significantly reduces the accumulation of fat in liver. On the other hand, (Hareeri et al., 2017)demonstrated that oral intake of (SO) caused a significant ( $p$ $<0.05)$ decreased in BWG\% and liver relative weight when compared to positive control group.

Effects of sage, sesame and olive oils alone or in combination on serum leptin hormone and blood glucose levels in obese nonalcoholic fatty liver rats.

Results presented in table (3) illustrate the effects of (HFD) alone and modified (HFD) by adding $5 \%$ sage or by replacing $20 \%$ (ST) to $20 \%$ from (SO), (OO) or mixed from (1:1 w/w) (SO) plus (OO) without or with $5 \%$ sage on leptin hormone and glucose levels in obese albino rats suffering from (NAFLD). Our results revealed that, serum leptin hormone and glucose levels in control (+ve) group fed on (HFD) were (10.678 \pm 0.65 and $142.387 \pm 4.888$ ), while control (-ve) group fed on (BD) recorded $(2.206 \pm 0.150$ and $77.856 \pm 3.688$, respectively). Statistical analysis showed a significant increase $(p<$ $0.05)$ in serum leptin and glucose levels of (+ve) control group fed on (HFD), as compared to (-ve) control group fed on (BD).

On the other hand, our results revealed that all groups fed on modified (HFD) by adding $5 \%$ sage or by replacing $20 \%$ from (ST) to $20 \%$ from (SO), (OO) or mixed $20 \%$ from (1:1 w/w) (SO) plus (OO) 
Egyptian J. of Nutrition Vol. XXXVI No. 1 (2021)

without or with $5 \%$ sage, recorded a significant decrease $(p<0.05)$ in serum leptin hormone and glucose levels in obese albino rats (NAFLD). The best results induced by the group fed on modified (HFD) by replacing 20 (ST) to $20 \%$ mixed from $(1: 1 \mathrm{w} / \mathrm{w})$ (SO) with (OO) plus $5 \%$ sage.

Our results are at a harmony with (Taha et al., 2014)who reported that supplementation with (SO) possess a better improving potential for hyperlipidemia, serum glucose, adiponectin, thyroid hormones, hepatic lipid profile. Concerning sage effect on blood glucose level (Eidi et al., 2005)suggested that aqueous extract of sage has been found to exhibit insulin - like activities. In this respect (Ben khedher et al., 2018)was found a marked improvement in insulin sensitivity by sage extract concern in olive oil a MUFA rich diet improves post prandial glucose, lipid and glyp-1 responses in insulin - resistant subject. On the other hand, our results are at the same line with (Frederich et al., 1995) who reported that the increase in leptin resistance as a result of consuming (HFD) in rodent, on the other side fat mass loss triggers a decrease in serum leptin level may reflect restoration of leptin sensivity (Pilcova et al.,2003).

\section{Conclusion}

In conclusion was drawn that replacing by $20 \%$ from saturated fatty acid sources sesame and olive oil $(1: 1 \mathrm{w} / \mathrm{w})$ plus $5 \%$ sage, ranged somewhere between them rise the effects of either component alone and induced the greatest improvement in case of 
Hadeer Ashraf Abd El-Aziz Abd El-Megeid, Seham A.M. Tharwat, Sonia S. El-Marasy and Ahmed E. Basyony.

obese (NAFLD) fed on (HFD). The present study showed that preliminary phytochemical analysis to sesame, olive oils and sage revealed the presence of flavonoids, phenolic compounds are of therapeutic value can be modifies liver fat patients in obese (NAFLD). 
Egyptian J. of Nutrition Vol. XXXVI No. 1 (2021)

Table (1): Effects of Sage, Olive and Sesame Oils Alone or in Combination on Feed intake and Body Weight Gain\% in Non-Alcoholic Fatty Liver Albino Rats.

\begin{tabular}{|c|c|c|c|}
\hline \multicolumn{2}{|c|}{$\begin{array}{ll}\text { Groups } & \text { Parameters } \\
\end{array}$} & $\begin{array}{c}\text { Feed Intake } \\
\text { (g/day/each rat) }\end{array}$ & BWG\% \\
\hline \multicolumn{2}{|c|}{ Control (-ve) group, fed on basal diet (BD). } & $\begin{array}{l}21.200^{a} \\
\pm 1.303\end{array}$ & $\begin{array}{l}19.260^{g} \\
\pm 0.708\end{array}$ \\
\hline \multicolumn{2}{|c|}{$\begin{array}{l}\text { Control (+ve) group, fed on high fat diet } \\
\text { (HFD). }\end{array}$} & $\begin{array}{l}18.800^{b} \\
\pm 0.836\end{array}$ & $\begin{array}{l}29.724^{\mathrm{a}} \\
\pm 1.084\end{array}$ \\
\hline \multirow{7}{*}{ 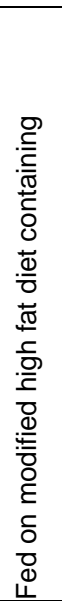 } & $5 \%$ sage & $\begin{array}{l}19.400^{b} \\
\pm 0.961\end{array}$ & $\begin{array}{l}26.833^{b} \\
\pm 1.082\end{array}$ \\
\hline & $20 \%$ olive oil "OO" & $\begin{array}{l}19.800^{b} \\
\pm 0.570\end{array}$ & $\begin{array}{l}26.398^{b c} \\
\pm 0.855\end{array}$ \\
\hline & $20 \%$ sesame oil "SO" & $\begin{array}{l}19.300^{b} \\
\pm 0.543\end{array}$ & $\begin{array}{l}25.723^{c} \\
\pm 0.606\end{array}$ \\
\hline & $10 \%$ OO plus $10 \%$ SO & $\begin{array}{l}19.600^{b} \\
\pm 0.418\end{array}$ & $\begin{array}{l}23.740^{d} \\
\pm 0.559\end{array}$ \\
\hline & $20 \%$ OO plus $5 \%$ sage & $\begin{array}{l}19.600^{b} \\
\pm 0.961\end{array}$ & $\begin{array}{l}23.244^{d e} \\
\pm 0.360\end{array}$ \\
\hline & $20 \%$ SO plus $5 \%$ sage & $\begin{array}{l}19.280^{b} \\
\pm 0.766\end{array}$ & $\begin{array}{l}22.519^{e} \\
\pm 0.963\end{array}$ \\
\hline & $10 \%$ OO plus $10 \%$ SO plus $5 \%$ sage & $\begin{array}{l}19.540^{b} \\
\pm 0.594\end{array}$ & $\begin{array}{l}21.068^{f} \\
\pm 0.525\end{array}$ \\
\hline
\end{tabular}

OO: Olive Oil SO: Sesame Oil These results are (Mean \pm SD)

BWG\%: Body weight gain\%. LSD: Least significant differences ( $\leq 0$

Mean values in each column with same letters are not significantly different. 
Hadeer Ashraf Abd El-Aziz Abd El-Megeid, Seham A.M. Tharwat, Sonia S. El-Marasy and Ahmed E. Basyony.

Table (2): Effects of Sage, Olive and Sesame Oils Alone or in Combination on Peritoneal Fat Pad and Some Organs Weight/Body Weight\% in Obese Albino Rats Suffering from Non-Alcoholic Fatty Liver Disease.

\begin{tabular}{|c|c|c|c|c|}
\hline \multirow{2}{*}{\multicolumn{2}{|c|}{ Groups $\quad$ Parameters }} & \multicolumn{2}{|c|}{$\begin{array}{c}\text { Organs weight / body } \\
\text { weight } \%\end{array}$} & \multirow[t]{2}{*}{ PFP \% } \\
\hline & & Liver & Kidney & \\
\hline \multicolumn{2}{|c|}{ Control (-ve) group } & $\begin{array}{l}2.615^{\mathrm{e}} \\
\pm 0.046\end{array}$ & $\begin{array}{l}0.511^{f} \\
\pm 0.023\end{array}$ & $\begin{array}{l}1.288^{h} \\
\pm 0.022\end{array}$ \\
\hline \multicolumn{2}{|c|}{$\begin{array}{l}\text { Control (+ve) group, fed on high fat diet } \\
\text { (HFD). }\end{array}$} & $\begin{array}{l}3.389^{a} \\
\pm 0.026\end{array}$ & $\begin{array}{l}0.784^{a} \\
\pm 0.015\end{array}$ & $\begin{array}{l}2.178^{\mathrm{a}} \\
\pm 0.046\end{array}$ \\
\hline \multirow{7}{*}{ 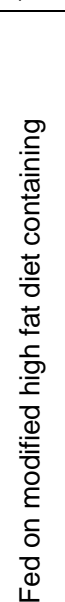 } & $5 \%$ sage & $\begin{array}{l}3.231^{b} \\
\pm 0.057\end{array}$ & $\begin{array}{l}0.687^{b} \\
\pm 0.032\end{array}$ & $\begin{array}{l}1.966^{\mathrm{b}} \\
\pm 0.037\end{array}$ \\
\hline & $20 \%$ olive oil "OO" & $\begin{array}{l}2.929^{c} \\
\pm 0.102\end{array}$ & $\begin{array}{l}0.651^{\mathrm{c}} \\
\pm 0.038\end{array}$ & $\begin{array}{l}1.856^{c} \\
\pm 0.042\end{array}$ \\
\hline & $20 \%$ sesame oil "SO" & $\begin{array}{l}2.829^{d} \\
\pm 0.064\end{array}$ & $\begin{array}{l}0.606^{\mathrm{de}} \\
\pm 0.025\end{array}$ & $\begin{array}{l}1.776^{d} \\
\pm 0.047\end{array}$ \\
\hline & $10 \%$ OO plus $10 \%$ SO & $\begin{array}{l}2.843^{d} \\
\pm 0.045\end{array}$ & $\begin{array}{l}0.611^{d} \\
\pm 0.010\end{array}$ & $\begin{array}{l}1.696^{\mathrm{e}} \\
\pm 0.039\end{array}$ \\
\hline & $20 \%$ OO plus $5 \%$ sage & $\begin{array}{l}2.790^{d} \\
\pm 0.077\end{array}$ & $\begin{array}{l}0.600^{\mathrm{de}} \\
\pm 0.009\end{array}$ & $\begin{array}{l}1.617^{\mathrm{fg}} \\
\pm 0.032\end{array}$ \\
\hline & $20 \%$ SO plus $5 \%$ sage & $\begin{array}{l}2.697^{e} \\
\pm 0.083\end{array}$ & $\begin{array}{l}0.595^{\mathrm{de}} \\
\pm 0.022\end{array}$ & $\begin{array}{l}1.678^{\text {ef }} \\
\pm 0.053\end{array}$ \\
\hline & $\begin{array}{l}10 \% \text { OO plus } 10 \% \text { SO plus } 5 \% \\
\text { sage }\end{array}$ & $\begin{array}{l}2.664^{\mathrm{e}} \\
\pm 0.035\end{array}$ & $\begin{array}{l}0.575^{\mathrm{e}} \\
\pm 0.012\end{array}$ & $\begin{array}{l}1.577^{\mathrm{g}} \\
\pm 0.086\end{array}$ \\
\hline
\end{tabular}

OO: Olive Oil SO: Sesame Oil These results are (Mean \pm SD)

BWG\%: Body weight gain\%. LSD: Least significant differences ( $\mathrm{P} \leq 0$ Mean values in each column with same letters are not significantly different. 
Egyptian J. of Nutrition Vol. XXXVI No. 1 (2021)

Table (3): Effects of Sage, Olive and Sesame Oils Alone or in Combination on Serum Leptin and Glucose in obese rats suffering from Non-Alcoholic Fatty Liver Disease.

\begin{tabular}{|c|c|c|c|}
\hline \multicolumn{2}{|c|}{$\begin{array}{ll}\text { Groups } & \text { Parameters } \\
\end{array}$} & $\begin{array}{l}\text { Leptin } \\
\mathrm{mg} / \mathrm{dl}\end{array}$ & $\begin{array}{c}\text { Glucose } \\
\mathrm{mg} / \mathrm{dl}\end{array}$ \\
\hline \multicolumn{2}{|c|}{ Control (-ve) group } & $\begin{array}{l}2.206^{g} \\
\pm 0.150\end{array}$ & $\begin{array}{l}77.856^{h} \\
\pm 3.688^{h}\end{array}$ \\
\hline \multicolumn{2}{|c|}{$\begin{array}{l}\text { Control (+ve) group, fed on high fat diet } \\
\text { (HFD). }\end{array}$} & $\begin{array}{l}10.678^{a} \\
\pm 0.654\end{array}$ & $\begin{array}{l}142.387^{a} \\
\pm 4.888\end{array}$ \\
\hline \multirow{7}{*}{ 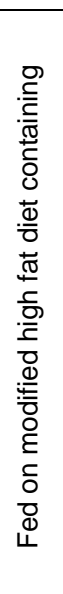 } & $5 \%$ sage & $\begin{array}{l}8.656^{b} \\
\pm 0.662\end{array}$ & $\begin{array}{r}127.234^{b} \\
\pm 3.515^{b}\end{array}$ \\
\hline & $20 \%$ olive oil "OO" & $\begin{array}{l}7.194^{c} \\
\pm 0.437\end{array}$ & $\begin{array}{r}117.949^{c} \\
\pm 2.542\end{array}$ \\
\hline & $20 \%$ sesame oil "SO" & $\begin{array}{l}6.678^{d} \\
\pm 0.285\end{array}$ & $\begin{array}{l}111.309^{d} \\
\pm 2.459\end{array}$ \\
\hline & $10 \%$ OO plus $10 \%$ SO & $\begin{array}{l}6.094^{e} \\
\pm 0.129\end{array}$ & $\begin{array}{r}104.298^{\mathrm{e}} \\
\pm 1.553\end{array}$ \\
\hline & $20 \%$ OO plus $5 \%$ sage & $\begin{array}{l}5.644^{\mathrm{e}} \\
\pm 0.132\end{array}$ & $\begin{array}{l}97.209^{f} \\
\pm 2.484\end{array}$ \\
\hline & $20 \%$ SO plus $5 \%$ sage & $\begin{array}{l}5.048^{f} \\
\pm 0.162\end{array}$ & $\begin{array}{l}91.275^{\mathrm{g}} \\
\pm 2.034\end{array}$ \\
\hline & $10 \%$ OO plus $10 \%$ SO plus $5 \%$ sage & $\begin{array}{c}4.986^{f} \\
\pm 0.303\end{array}$ & $\begin{array}{l}87.403^{\mathrm{g}} \\
\pm 3.874\end{array}$ \\
\hline
\end{tabular}

BWG\%: Body weight gain\%. LSD: Least significant differences ( $\mathrm{P} \leq 0$

Mean values in each column with same letters are not significantly different. 
Hadeer Ashraf Abd El-Aziz Abd El-Megeid, Seham A.M. Tharwat, Sonia S. El-Marasy and Ahmed E. Basyony.

\section{References}

Antunes, C. and Bhimji, S. (2017):

Fatty liver. Stat Pearls. Treasure Island (FL): Stat pearls Publishing; PMID:28723021.

Bellentani, S. and Marino, M. (2009).

Epidemiology and natural history of non-alcoholic fatty liver disease (NAFLD). Annals Hepatology; 8(Suppl. 1): S4-8.

Bellentani, S. and Tiribelli, C. (2001).

The spectrum of liver disease in the general population. Journal of Hepatology., 35 (4): 531-537.

Ben Khedher, M.R.; Hammami, M.; Arch, S.R.J.; Hislop, C.D.; Eze, D.; Wargent,T.E.; Kępczyńska, A.M.; and Zaibi, S.M. (2018).

Preventive effects of Salvia officinalis leaf extract on insulin resistance and inflammation in a model of high fat dietinduced obesity in mice that responds to rosiglitazone.Peer Journal, 6: e4166. 
Egyptian J. of Nutrition Vol. XXXVI No. 1 (2021)

Capanni, M.; Calella, F.; Biagini, M.R.; Genise, S.; Raimondi, L.; Bedogni, G.; Svegliati-Baroni, G.; Sofi, F.; Milani, S. and Abbate, R. (2006).

Prolonged n-3 polyunsaturated fatty acid supplementation ameliorates hepatic steatosis in patients with non-alcoholic fatty liver disease: a pilot study. Alimentary Pharmacology \& Therapeutics; 23:1143-1151

Carla, M.; Alice, S.; Ramos, A.; Marisa, F.; Azevedo Cristovao, F.; Lima, M. F. F and Cristina, P.W. (2009).

Sage Tea Drinking Improves Lipid Profile and Antioxidant Defences in Humans. International Journal of Molecular Sciences, 10: 3937-3950.

Chapman, D.G.; Castilla, R. and Campbell, J.A. (1959).

Evaluation of protein in food. Determination of protein and food efficiency ratio. Canadian Journal Of Biochemistry and Physiology., 37: 679-686.

Chien,C.F.; Wu, Y.T. and Tsai,T.H. (2011).

Biological analysis of herbal medicines used for the treatment of liver disease. Biomedical Chromatography., 25 (1-2):21-38. 
Hadeer Ashraf Abd El-Aziz Abd El-Megeid, Seham A.M. Tharwat, Sonia S. El-Marasy and Ahmed E. Basyony.

Eidi, M.; Eidi, A. and Zamanizadeh, H. (2005).

Effect of Salvia officinalis L. leaves on serum glucose and insulin in healthy and streptozotocin-induced diabetic rats. Journal of Ethnopharmacology; 100 (3): 310-313.

Fabbrini, E.; deHaseth, D.; Deivanayagam, S.; Mohammed, B.S.; Vitola, B.E. and Klein, S.(2009).

Alterations in fatty acid kinetics in obese adolescents with increased intrahepatic triglyceride content. Obesity (Silver Spring), 17, 25-29.

Frederich, R.C.; Hamann, A.; Anderson, S.; Lollmann, B.; Lowell, B.B. \& Flier, J.S. (1995).

Leptin levels reflect body lipid content in mice: Evidence for diet-induced resistance to leptin action. Nature medicine, 1 (12): 1311-1314.

Guillaume, M. and Bjorntorp, P. (1996).

Obesity in Children, environmental and genetic aspects. Hormone and Metabolic Research. 28, 573-581. 
Egyptian J. of Nutrition Vol. XXXVI No. 1 (2021)

Hamidpour, M.; Hamidpour, R.; Hamidpour, S. and Shahlar, M. (2014).

Chemistry, Pharmacology, and Medicinal Property of Sage (Salvia) to Prevent and Cure Illnesses such as Obesity, Diabetes, Depression, Dementia, Lupus, Autism, Heart Disease, and Cancer. Journal of Traditional and Complementary Medicine.; 4(2): 82-88.

Han, L.K., Kimura, Y. and Okuda, H. (1999).

Reduction in Fat Storage during Chitin-Chitosan Treatment in Mice Fed a High Fat Diet. International Journal of Obesity, 23, 174-179.

Han, L.K.; Sumiyoshi, M.; Takida, T.; Chihara, H.; Nishikiori, T. and Tsujita, T. (2000)

Inhibitory Effects of Chondroitin Sulfate Prepared from Salmon Nasal Cartilage on Fat Storage on Mice Fed a High Fat Diet. International Journal of Obesity, 24, 1131-1138.

Hareeri, Nahed A.; Alrasheedi, Amani A. and Eassaw, Mamdouh M. (2017).

Effect of sesame on liver enzymes and lipid profile inrats exposed to oxidative stress induced by Monosodium glutamate.J. of American Science. 2017;13(1): 71-78. 
Hadeer Ashraf Abd El-Aziz Abd El-Megeid, Seham A.M. Tharwat, Sonia S. El-Marasy and Ahmed E. Basyony.

Kaippert, V.C.; Lopes, M.C.; Carvalho, P.D. and Rosad, E.L. (2015).

Effects of unsaturated fatty acids on weight loss, body composition and obesity related biomarkers. Diabetology \& Metabolic Syndrome, 7 (1): A139.

Leite, N.C.; Salles, G.F.; Araujo, A.L.; Villela-Nogueira, C.A. and Cardoso, C.R. (2009):

Prevalence and associated factors of non-alcoholic fatty liver disease in patients with type 2 diabetes mellitus. Liver International., 29 (1):113-119.

Lonardo, A.; Ballestri,S.; Marchesini, G.; Angulo, P. and Loria, P. (2015).

Nonalcoholic fatty liver disease: A precursor of the metabolic syndrome. Digestive and Liver Disease; 47 (3):181-190.

Pilcova, R.; Sulcova, J.; Hill, M.; Blaha, P. and Lisa, L. (2003). Leptin Levels in Obese Children: Effects of Gender, Weight Reduction and Androgens. Physiological Research. 52: 5360. 
Egyptian J. of Nutrition Vol. XXXVI No. 1 (2021)

Samuel, V.T.; Liu, Z.X.; Qu, X.; Elder, B.D.; Bilz, S.; Befroy, D.; Romanelli, A.J. and Shulman, G.I. (2004).

Mechanism of hepatic insulin resistance in non-alcoholic fatty liver disease. Journal of Biological Chemistry 279: 3234532353.

Sankar, D.; Ramakrishna Rao, M.; Sambandam, G. and Pugalendi, K.V. (2006):

A pilot study of open label sesame oil in hypertensive diabetes. Journal of Medicinal Food., 9 (3): 408-412.

SAS. (2004):

Statistical analysis system, SAS Users Guide : Statistics . SAS Institute Inc, Editors, Cary, NC.

Taha, N.; Mandour, A.; Mohamed, M. and Emarha, R. (2014). Effect of Sesame Oil on Serum and Liver Lipid Profile in Hyperlipidemic Rats. Alexandria Journal of Veterinary Sciences, 42: 17-25.

Trinder, P. (1969):

Determination of blood glucose using U- Amino penzanone . Journal of Clinical Pathology, 22: 246. 
Hadeer Ashraf Abd El-Aziz Abd El-Megeid, Seham A.M. Tharwat, Sonia S. El-Marasy and Ahmed E. Basyony.

Wani, F.A.; Albahrawy, A.Z. and Rahiman, S. (2015).

Hypolipidemic Activity of Olive Oil (Olea europaea) against High Fat Diet-Induced Nonalcoholic Fatty Liver Disease (NAFLD) in Mice. Open Journal of Pathology, 5: 73-83.

Yki-Jarvinen, H. (2005).

Fat in the liver and insulin resistance. Annals of Medicine; 37:347-356.

Zarghani, S.S.; Soraya, H.; Zarei, L. and Alizadeh, M. (2016). Comparison of Three Different Diet-Induced Non Alcoholic Fatty Liver Disease Protocols in Rats: A Pilot Study. Pharmaceutical Sciences, 22, 9-15. 
Egyptian J. of Nutrition Vol. XXXVI No. 1 (2021)

تأثير المرمرية، وزيوت السمم والزيتون منفردا أو مع المرمرية علي

إنقاص الوزن ومستوى سكر الدم في فئران الالبينو البدينة المصابة بتدهن

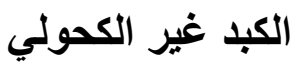

هاير اشرف عبد العزيز عبد المجيد* - سهام عباس محمود ثروت* سونيا

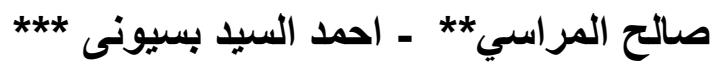

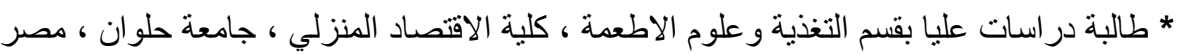

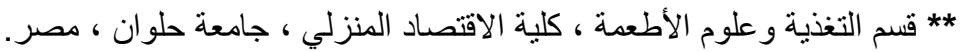
ا ل

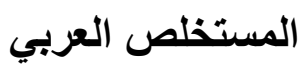

الهفف من هذه الدراسة هو معرفة نأثير المرمرية "المريمية" وزيت السمسم و الزيتون

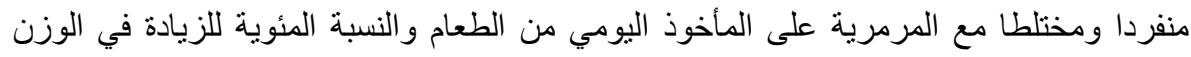

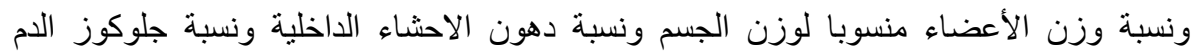

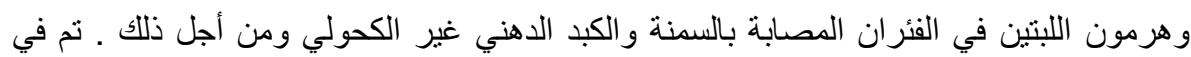

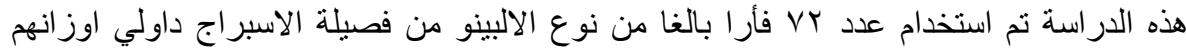

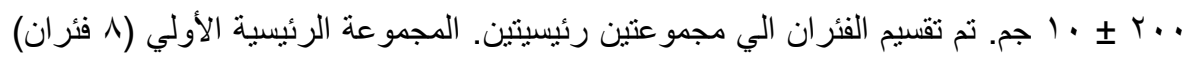

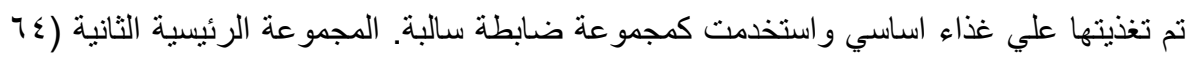

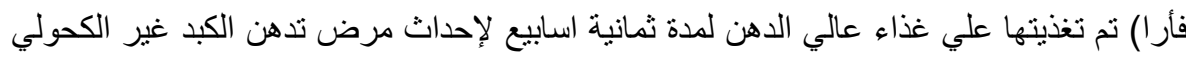

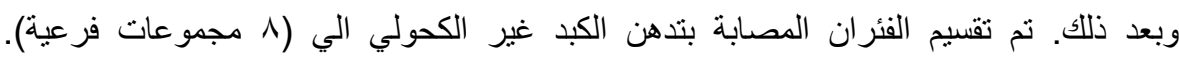


Hadeer Ashraf Abd El-Aziz Abd El-Megeid, Seham A.M. Tharwat, Sonia S. El-Marasy and Ahmed E. Basyony.

مجموعة منهم (^ فئر ان) تم تغذيتها علي غذاء عالي الدهن واستخدمت كمجموعة ضابطة ايجابية "مصابة". المجموعات السبع الفرعية الاخري نم تغذيتها علي نظام غذائي معدل عالي الدهن. مجموعة منهم تم تغذيتها علي غذاء عالي الدهن تحتوى علي ٪\% مرمرية. المجموعات الفرعية

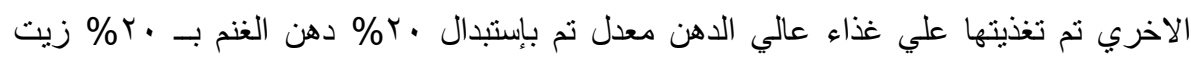

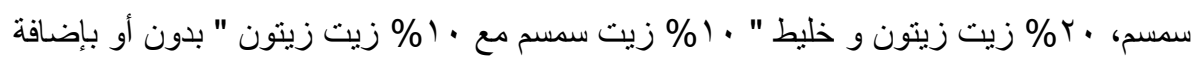
المرمرية لمدة (^ اسابيع). في نهاية فترة التجربة، نم ذبح الفئران بعد صيام طوال الليل، ثم نم فصل الكبد و الكلي ودهون الاحشاء الداخلية وتم وزنهم. تم تجميع الدم، ثم فصل السيرم، نم تقدير نهري مستوى الجلوكوز و الليبتين. أثنارت النتائج المتحصل عليها الي ان تغذية الفئران البدينة المصابة

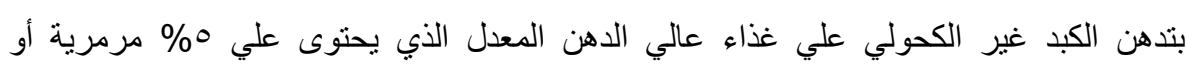

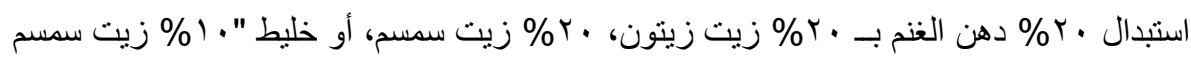

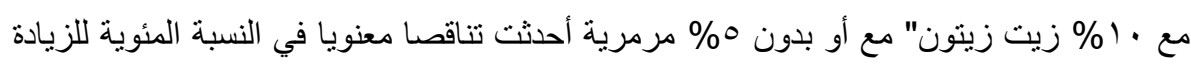

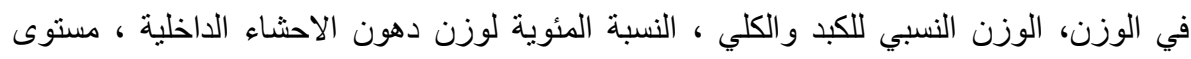

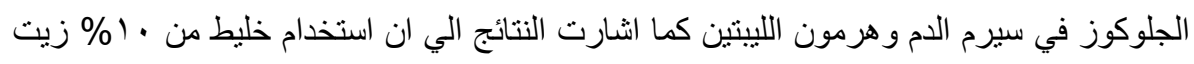

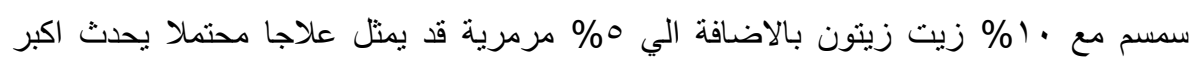
انخفاضا في النسبة المئوية للزيادة في الوزن، الوزن النسبي للاعضاء، النسبة المئوية لوزن دهون

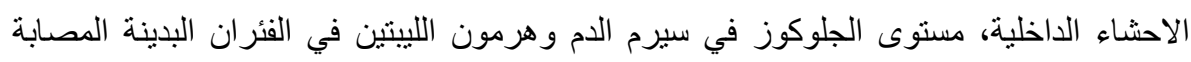
بتدهن الكبد غير الكحولي. 